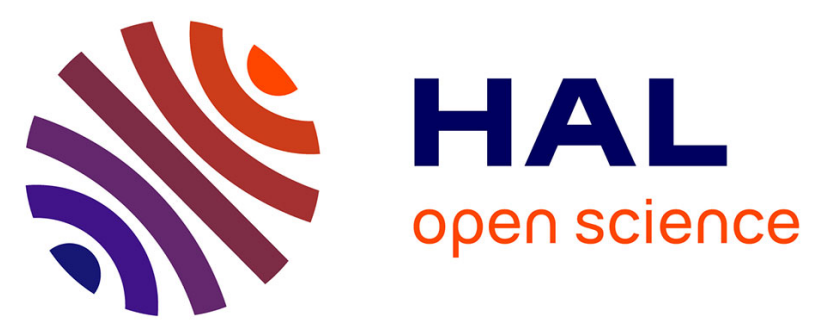

\title{
Bicapped Keggin polyoxomolybdates: discrete species and experimental and theoretical investigations on the electronic delocalization in a chain compound
}

William Salomon, Eric Rivière, Xavier Lopez, Nicolas Suaud, Pierre Mialane, Mohamed Haouas, Ali Saad, Jérôme Marrot, Anne Dolbecq

\section{To cite this version:}

William Salomon, Eric Rivière, Xavier Lopez, Nicolas Suaud, Pierre Mialane, et al.. Bicapped Keggin polyoxomolybdates: discrete species and experimental and theoretical investigations on the electronic delocalization in a chain compound. Dalton Transactions, 2018, 47 (31), pp.10636-10645. $10.1039 /$ c8dt01313f . hal-02335632

\section{HAL Id: hal-02335632 \\ https://hal.science/hal-02335632}

Submitted on 28 Oct 2019

HAL is a multi-disciplinary open access archive for the deposit and dissemination of scientific research documents, whether they are published or not. The documents may come from teaching and research institutions in France or abroad, or from public or private research centers.
L'archive ouverte pluridisciplinaire HAL, est destinée au dépôt et à la diffusion de documents scientifiques de niveau recherche, publiés ou non, émanant des établissements d'enseignement et de recherche français ou étrangers, des laboratoires publics ou privés. 


\title{
Journal Name
}

\section{ARTICLE}

\section{Bicapped Keggin polyoxomolybdates: discrete species and investigations on the electronic delocalization in a chain compound}

Received 00th January 20xx Accepted 00th January 20xx

DOI: $10.1039 / x 0 x \times 00000 x$

www.rsc.org/
William Salomon, ${ }^{a}$ Eric Rivière, ${ }^{b}$ Xavier Lopez, ${ }^{c}$ Nicolas Suaud, ${ }^{d}$ Pierre Mialane, ${ }^{a}$ Mohamed Haouas, ${ }^{a}$ Ali Saad, ${ }^{a}$ Jérôme Marrot, ${ }^{a}$ and Anne Dolbecq $*^{a}$

\begin{abstract}
Three monomeric polyoxometalates $\left[\mathrm{M}\left(\mathrm{C}_{10} \mathrm{H}_{8} \mathrm{~N}_{2}\right)_{3}\right]\left[\alpha-\mathrm{PMo}_{9}^{\mathrm{VI}} \mathrm{Mo}_{3}{ }_{3} \mathrm{O}_{40} \mathrm{Zn}_{2}\left(\mathrm{C}_{10} \mathrm{H}_{8} \mathrm{~N}_{2}\right)_{2}\right] \cdot 2 \mathrm{H}_{2} \mathrm{O}\left(\mathbf{M}-\mathbf{P M o _ { 1 2 }} \mathrm{Zn_{2 }}, \mathrm{M}=\mathrm{Fe}, \mathrm{Co}, \mathrm{Ru}\right)$ with $\left\{\mathrm{Zn}(\mathrm{bpy})_{2}\right\}^{2+}$ units capped on reduced $\alpha$-Keggin polyanions and $\left[\mathrm{M}(\mathrm{bpy})_{3}\right]^{2+}$ counter-ions were synthesized under hydrothermal conditions. The 1D polymer $\left[\mathrm{N}\left(\mathrm{C}_{4} \mathrm{H}_{9}\right)_{4}\right]\left[\mathrm{Ru}\left(\mathrm{C}_{10} \mathrm{H}_{8} \mathrm{~N}_{2}\right)_{3}\right]\left[\alpha-\mathrm{PMo}^{\mathrm{VI}}{ }_{8} \mathrm{Mo}_{6}{ }_{6} \mathrm{O}_{43}\right]\left(\mathrm{Ru}-\mathrm{PMo}_{14}\right)$ was prepared by a similar strategy. In this chain capped reduced Keggin anions are linked via Mo-O-Mo bridges and are surrounded by both TBA ${ }^{+}$and $\left[\mathrm{Ru}(\mathrm{bpy})_{3}\right]^{2+}$ counter-ions. The compounds were characterized in the solid state by single crystal and powder $\mathrm{X}$-ray diffraction and IR spectroscopy and in solution by ${ }^{31} \mathrm{P} N M R$ spectroscopy. ${ }^{31} \mathrm{P}$ diffusion ordered NMR spectroscopy (DOSY) indicates that the diffusion coefficient of the dissolved species of $\mathbf{R u}-\mathbf{P M O}_{\mathbf{1 4}}$ could correspond to a dimeric structure. Magnetic susceptibility measurements performed on Ru-PMo ${ }_{14}$ show the existence of antiferromagnetic interactions between the $d^{1}$ electrons of the six $\mathrm{Mo}^{v}$ centers at low temperature and a delocalization of these electrons at high temperature. DFT calculations allowed proposing a distribution of the electrons consistent with this magnetic behaviour.
\end{abstract}

\section{Introduction}

Polyoxometalates (POMs) are usually described as soluble anionic metal oxide clusters of d-block transition metals in high oxidation states $\left(\mathrm{W}^{\mathrm{Vl}}, \mathrm{Mo}^{\mathrm{V}, \mathrm{Vl}}, \mathrm{V}^{\mathrm{l}, \mathrm{V}}\right)$. $^{1}$ They are considered as intermediate species between metalate ions in solution and dense oxide solid phases. Keggin ions with the general formula $\left\{X_{12} \mathrm{O}_{40}\right\}(X=P, S i, G e, A s$, etc., $M=M o, W, V, N b$, etc., noted $\left.\mathrm{XM}_{12}\right)^{2}$ represent one of the most studied family of POMs for several reasons: i) they are synthesized in water by a one step procedure but organic soluble derivatives can also be easily obtained, ii) they possess various compositions, iii) vacant species can be easily formed, especially for the $\mathrm{XW}_{12}$ series, while the $\mathrm{XMo}_{12}$ series can be reduced up to 24 electrons, giving access to larger and/or functionalized species as well as POM-based materials, ${ }^{3}$ and finally iv) they exhibit a wide range of properties from magnetic to catalytic properties. ${ }^{4}$ There is thus a great interest in studying the condensation process from a single isolated Keggin ion to larger structures. One way

\footnotetext{
Institut Lavoisier de Versailles, UMR 8180 CNRS, Université de Versailles SaintQuentin en Yvelines, 45 Avenue des Etats-Unis, 78035 Versailles cedex, France. Email : anne.dolbecq@uvsq.fr

${ }^{b .}$ Institut de Chimie Moléculaire et des Matériaux d'Orsay, CNRS, Université Paris Sud and Université Paris Saclay, Orsay, Cedex 91405, France.

Departament de Química Física i Inorgànica, Universitat Rovira i Virgili, Marcel•lí Domingo 1, 43007 Tarragona, Spain.

${ }^{d .}$ Laboratoire de Chimie et Physique Quantique, IRSAMC, Université de Toulouse Paul Sabatier, 118 route de Narbonne, 31062 Toulouse Cedex, France.

+ Electronic Supplementary Information (ESI) available: Computational and experimental details. See DOI: 10.1039/x0xx00000x
}

to increase the reactivity of the $\mathrm{XMo}_{12}$ Keggin ion lies in the reduction which increases the negative charge of the POM and thus its nucleophilicity, favoring the aggregation processes through its reaction with electrophiles. In this respect, hydrothermal reactions have allowed to synthesize a large variety of bi-capped molecular anions such as $[\alpha-$ $\left.\mathrm{PMo}_{3}{ }_{3} \mathrm{Mo}^{\mathrm{VI}}{ }_{9} \mathrm{O}_{40}\left\{\mathrm{Cu}^{\prime \prime}(\mathrm{bpy})\right\}_{2}\right]^{2-, 5}, \quad\left[\alpha-\mathrm{PMo}^{\mathrm{V}}{ }_{4} \mathrm{Mo}^{\mathrm{VI}}{ }_{8} \mathrm{O}_{40}\left\{\mathrm{Co}{ }^{\prime \prime}(\mathrm{bpy})\right\}_{2}\right]^{3-}$ ${ }^{6}\left[\alpha-\mathrm{PMo}_{3}{ }_{3} \mathrm{Mo}^{\mathrm{VI}}{ }_{9} \mathrm{O}_{40}\left\{\mathrm{M}^{\prime \prime}(\text { phen })\right\}_{2}\right]^{2-}\left(\mathrm{M}=\mathrm{Ni}^{7} \mathrm{Cr}^{8}\right)$ and $[\alpha-$ $\left.\mathrm{PMO}_{6}{ }_{6} \mathrm{MoO}_{6}{ }_{6} \mathrm{O}_{40}\left(\mathrm{~V}^{\mathrm{IV}} \mathrm{O}\right)_{2}\right]^{5-}$. 9 Controlled reduction of $\left[\mathrm{PMO}_{12} \mathrm{O}_{40}\right]^{3-}$ with sodium amalgam in the presence of metal halides have also led to mono-capped $\left[\mathrm{PMo}_{12} \mathrm{O}_{40}\left\{\mathrm{Co}(\mathrm{MeCN})_{2}\right\}\right]^{3-}$, and bicapped $\quad\left[\alpha-\mathrm{PMo}^{\mathrm{V}}{ }_{4} \mathrm{Mo}^{\mathrm{VI}}{ }_{8} \mathrm{O}_{40}\left(\mathrm{~V}^{\mathrm{IV}} \mathrm{O}\right)_{2}\right]^{3-}$ and $[\alpha-$ $\left.\mathrm{PMo}_{6}{ }_{6} \mathrm{Mo}_{6}{ }_{6} \mathrm{O}_{40} \mathrm{Sb}_{2}{ }_{2}\right]^{3-}$ POMs. ${ }^{10}$ When the negative charge of the Keggin core increases, by reducing a higher number of $\mathrm{Mo}^{\mathrm{VI}}$ or by introducing $\mathrm{V}^{\mathrm{IV}}$ ions, tetra-capped species can be isolated, for example $\left[\alpha-\mathrm{PMo}_{6}{ }_{6} \mathrm{Mo}_{2}{ }_{2} \mathrm{~V}^{\mathrm{VV}}{ }_{8} \mathrm{O}_{44}\left\{\mathrm{Co}(\mathrm{bpy}){ }_{2}\left(\mathrm{H}_{2} \mathrm{O}\right)\right\}_{4}\right]^{3+}$ ${ }^{7}$ or $\left\{\varepsilon-\mathrm{PMo}_{4}{ }_{4} \mathrm{MoO}_{8}{ }_{8}(\mathrm{ML})_{4}\right\}\left(\mathrm{M}=\mathrm{La}^{\mathrm{III}},{ }^{11} \mathrm{Ni}^{11}, \mathrm{Co}^{\prime \prime}, \mathrm{Zn}^{\prime \prime} ;{ }^{12} \mathrm{~L}=\mathrm{N}\right.$ donor or carboxylate ligand). It should be noticed that in the case of eight-electron reduced $\mathrm{PMo}_{12}$ Keggin ions, the stable isomer is no more the $\alpha$ isomer but the $\varepsilon$ one..$^{13}$ In the absence of hetero transition metal ions, extra $\left\{\mathrm{MoO}_{2}\right\}$ groups aggregate on the surface of the $\mathrm{XMo}_{12}$ core $\left(\mathrm{X}=\mathrm{Si}^{14}{ }^{14} \mathrm{Al},{ }^{15} \mathrm{P}^{16}\right)$ to form bicapped $\mathrm{XMO}_{14}$ species. Finally, in rare examples, the condensation process does not stop to the aggregation of two or four capping groups but leads to dimerized,Erreur ! Signet non défini. ${ }^{a}$ and even 1D structures. In $\{\alpha$ $\left.\mathrm{Mo}^{\mathrm{VI}}{ }_{8} \mathrm{~V}^{\mathrm{IV}}{ }_{4} \mathrm{O}_{36}\left(\mathrm{~V}^{\mathrm{V}} \mathrm{O}_{4}\right)\right\}^{17}$ the connection is ensured by capping and bridging $\left\{\mathrm{V}^{\mathrm{IV}}{ }_{2} \mathrm{O}_{2}\right\}^{4+}$ groups while in $\left\{\alpha-\mathrm{PMo}^{\mathrm{VI}}{ }_{10} \mathrm{Mo}_{2}{ }_{2} \mathrm{O}_{39}\right\}^{18}$ there is no capping groups and the POMs are directly linked via 
a common terminal atom shared by two adjacent $\mathrm{PMo}_{12}$. Note that another way to build Keggin based chains is to connect vacant polyoxotungstate units via $\mathrm{W}-\mathrm{O}-\mathrm{M}$ bridges $\left(\mathrm{M}=\mathrm{Mn},{ }^{19}\right.$ $\mathrm{Cu}^{20}{ }^{20} \mathrm{Co}^{21}$ ) where the heterometal ion $\mathrm{M}$ occupies the vacancy of the lacunary anion. 1D coordination polymers based on Keggin-type $\left[\mathrm{SiW}_{12} \mathrm{O}_{40}\right]^{4-}$ and $\mathrm{Pb}^{2+}$ ions ${ }^{22}$ as well as 1D polyoxovanadates ${ }^{23}$ have also been reported. Following our previous studies on $\varepsilon$-Keggin based materials, ${ }^{24}$ we report here the hydrothermal synthesis of bi-capped $\mathrm{PMo}_{12}$ compounds either molecular or connected to form a 1D chain. These compounds were characterized in the solid state and in solution by a variety of techniques. DFT calculations were also carried out and brought valuable information about the localization of the electrons.

\section{Results and discussion}

\section{Synthesis and characterisations}

The synthesis of $\left[\mathrm{N}\left(\mathrm{C}_{4} \mathrm{H}_{9}\right)_{4}\right]\left[\mathrm{Ru}\left(\mathrm{C}_{10} \mathrm{H}_{8} \mathrm{~N}_{2}\right)_{3}\right]\left[\mathrm{PMo}^{\mathrm{V}}{ }_{8} \mathrm{MoV}_{6} \mathrm{O}_{43}\right] \quad$ (Ru$\mathrm{PMo}_{14}$ ) was performed by the reaction of a $\mathrm{Mo}^{\mathrm{VI}}$ precursor, Mo as reducing agent, $\mathrm{H}_{3} \mathrm{PO}_{3}$ as a source of heteroelement, zinc acetate, terephtalic acid and $\mathrm{TBAOH}$ in water at $200^{\circ} \mathrm{C}$, following the usual procedures for the synthesis of POMOFs materials, with however the following modifications: i) a lower initial $\mathrm{pH}(\mathrm{pH}=4$ compared to the usual pH 5);Erreur ! Signet non défini. ii) the solution was degassed with $\mathrm{Ar}$ before heating and iii) $\left[\mathrm{Ru}(\mathrm{bpy})_{3}\right]^{2+}$ complexes were introduced as counter-ions with the aim to replace totally or partially the $\mathrm{TBA}^{+}$cations usually present as non-innocent counterions. These modifications of the conditions previously used to generate in situ the $\left[\varepsilon-\mathrm{PMo}_{4}{ }_{4}^{\mathrm{VI}} \mathrm{Mo}_{8}{ }_{8} \mathrm{O}_{40}\right]^{11-}$ core led here to $\alpha$ isomers with the mean formula $\left[\alpha-\mathrm{PMo}^{\mathrm{VI}}{ }_{8} \mathrm{Mo}^{\mathrm{V}}{ }_{4} \mathrm{O}_{40}\right]^{7-}$ where the degree of reduction of the $\mathrm{Mo}^{\mathrm{VI}}$ ions is only 4 compared to 8 in the $\varepsilon$ derivative. These POMs are capped by $\left\{\mathrm{Mo}^{\vee} \mathrm{O}_{2}\right\}^{+}$groups which connect to form a 1D chain (see below). $\mathrm{TBA}^{+}$ions and $\left[\mathrm{Ru}(\mathrm{bpy})_{3}\right]^{2+}$ complexes are both present as counter-ions in a 1:1 ratio. Note that the presence of zinc acetate and terephtalic acid is necessary during the synthesis although these reactants do not appear in the final product, and that degassing with Ar appeared also to be crucial to get Ru-PMo ${ }_{14}$.

The $\left[\mathrm{M}\left(\mathrm{C}_{10} \mathrm{H}_{8} \mathrm{~N}_{2}\right)_{3}\right]\left[\mathrm{PMo}^{\mathrm{VI}}{ }_{9} \mathrm{Mo}_{3}^{\mathrm{V}} \mathrm{O}_{40} \mathrm{Zn}_{2}\left(\mathrm{C}_{10} \mathrm{H}_{8} \mathrm{~N}_{2}\right)_{2}\right] \cdot 2 \mathrm{H}_{2} \mathrm{O} \quad$ M$\mathbf{P M o}_{12} \mathbf{Z n}_{2}$ ( $\mathrm{M}=\mathrm{Fe}, \mathrm{Co}$ ) molecular phases were first obtained in similar conditions to that used for the synthesis of Ru-PMo $\mathbf{~}_{14}$, with $\left[\mathrm{M}(\mathrm{bpy})_{3}\right]^{2+}(\mathrm{M}=\mathrm{Fe}, \mathrm{Co})$ replacing $\left[\mathrm{Ru}(\mathrm{bpy})_{3}\right]^{2+}$ cations. Surprisingly, we observed the partial decomposition of these complexes, which are less stable than their $\mathrm{Ru}$ analogue, and the formation of $\alpha$ isomers with the formula $\left[\alpha-\mathrm{PMo}^{\mathrm{VV}}{ }_{9} \mathrm{Mo}^{\mathrm{V}}{ }_{3} \mathrm{O}_{40}\right]^{6-}$ capped by two $\{\mathrm{Zn}(\mathrm{bpy})\}^{2+}$ groups with $\left[\mathrm{M}(\mathrm{bpy})_{3}\right]^{2+}(\mathrm{M}=\mathrm{Fe}, \mathrm{Co})$ counter-cations. The synthesis was further rationalized by introducing bpy ligands and removing terephtalic acid. For these syntheses, it was not necessary to degas the solution and the initial $\mathrm{pH}$ was the usual $\mathrm{pH}$ 5 . $\left[\mathrm{Ru}\left(\mathrm{C}_{10} \mathrm{H}_{8} \mathrm{~N}_{2}\right)_{3}\right]\left[\mathrm{PMo}_{9}{ }_{9}^{\mathrm{VI}} \mathrm{Mo}_{3}{ }_{3} \mathrm{O}_{40} \mathrm{Zn}_{2}\left(\mathrm{C}_{10} \mathrm{H}_{8} \mathrm{~N}_{2}\right)_{2}\right] \cdot 4 \mathrm{H}_{2} \mathrm{O} \quad\left(\right.$ Ru-PMo $\left.\mathbf{P O}_{12} \mathrm{Zn}_{\mathbf{2}}\right)$ was also synthesized.

The infrared spectra of $\mathbf{M}-\mathbf{P M o}_{\mathbf{1 2}} \mathbf{Z} \mathbf{n}_{\mathbf{2}}(\mathbf{M}=\mathrm{Fe}, \mathrm{Co}, \mathrm{Ru})$ are similar and exhibit several characteristic regions (Fig. S1). The 1700-1150 $\mathrm{cm}^{-1}$ region is indicative of the $2,2^{\prime}$-bpy organic ligand. The P-O vibrations are observed between 1000 and $1100 \mathrm{~cm}^{-1}$. The third characteristic region is located between 700 and $950 \mathrm{~cm}^{-1}$. The strong band around $930 \mathrm{~cm}^{-1}$ is assigned to the Mo=O stretching vibrations and peaks between 700 and $900 \mathrm{~cm}^{-1}$ are attributed to Mo-O-Mo stretching modes. The IR spectrum of Ru-PMo $\mathbf{P}_{14}$ is close to those of the molecular compounds with the additional presence of weak $\delta_{C-H}$ vibrations around $1480 \mathrm{~cm}^{-1}$ characteristic of the TBA ${ }^{+}$ cations. It can also be noted that the $v(\mathrm{Mo}=0)$ band is at a higher energy $\left(946 \mathbf{c m}^{-1}\right.$ ) than for the $\mathbf{M}-\mathbf{P M o}_{12} \mathbf{Z n}_{\mathbf{2}}$ complexes, in agreement with a greater number of $\mathrm{Mo}^{\mathrm{V}}$ reduced sites. Erreur ! Signet non défini. ${ }^{\mathrm{a}, 25}$

\section{Structures}

The structures of $\mathbf{R u}-\mathbf{P M O}_{12} \mathbf{Z} \mathbf{n}_{\mathbf{2}}$ and $\mathbf{R u} \mathbf{\mathbf { P }} \mathbf{P} \mathbf{M o}_{14}$ were determined by single crystal $X$-ray diffraction. The comparison of the experimental X-ray powder patterns of $\mathbf{F e}-\mathbf{P M O}_{12} \mathbf{Z} \mathbf{n}_{2}, \mathbf{C o}-\mathbf{P M o}_{12} \mathbf{Z} \mathbf{n}_{\mathbf{2}}$ and $\mathbf{R u}$ $\mathbf{P M o}_{12} Z_{2} n_{2}$ with the powder pattern calculated from the structure of $\mathbf{R u}-\mathbf{P M O}_{12} \mathbf{Z n}_{2}$ solved from single-crystal X-ray diffraction data indicates that the three phases are isostructural and shows their crystalline homogeneity (Fig. S2-S3). The POM core, common in the structures of Ru-PMo $\mathbf{P M}_{12} \mathbf{Z n}_{\mathbf{2}}$ and $\mathbf{R u}-\mathbf{P M o}_{14}$, consists in a $\alpha-\mathbf{P M o}_{12}$ Keggin anion (Fig. 1). This POM core is reduced and the degree of reduction was deduced from charge balance considerations. Bond valence sum calculations (Fig. S4-S5) confirm the reduction of the POM but do not show clearly a localization of the $\mathrm{Mo}^{\vee} d^{1}$ electrons within the $\alpha-\mathrm{PMo}_{12}$ anion.

As the negative charge of the Keggin core increases, its nucleophilicity becomes also higher and electrophilic groups aggregate to it. The nature of the capping groups are different in the two structures: two $\left\{\mathrm{Mo}^{\mathrm{V}} \mathrm{O}_{2}\right\}^{2+}$ groups cap two opposite tetragonal faces of the Keggin core in Ru-PMo ${ }_{14}$ (Fig. 1a) whereas in the case of $\mathbf{R u}-\mathbf{P M o}_{12} \mathbf{Z n _ { 2 }}$ two $\{\mathbf{Z n}(\mathrm{bpy})\}^{2+}$ groups stabilize the negatively charged POM (Fig. 1b). In both cases, the metals are in octahedral environments and bound to four bridging oxygen atoms of the POM, which are usually considered as the most basic sites. ${ }^{26}$ This disposition is common to the bi-capped POM structures previously reported either with $\{\mathrm{M}(\mathrm{bpy})\}(\mathrm{M}=\mathrm{Cu}, \mathrm{Co})$,Erreur ! Signet non défini. Erreur! Signet non défini. $\left\{\right.$ VO\}Erreur ! Signet non défini. or $\left\{\mathrm{MoO}_{2}\right\}$ Erreur ! Signet non défini. capping groups. It is quite different to that observed in the $\varepsilon$-Keggin species $\left\{\varepsilon\right.$-PMo $\left.{ }_{4}{ }_{4} \mathrm{Mo}^{\mathrm{V}}{ }_{8} \mathrm{O}_{40} \mathrm{Zn}_{4}\right\}$ where four $\mathrm{Zn}$ " ions in tetrahedral coordination cap the hexagonal faces of the eightelectron reduced $\varepsilon$-Keggin isomer (Fig. S6).Erreur ! Signet non défini.

In Ru-PMo ${ }_{14}$ adjacent POMs share a single common $\mathrm{O}$ atom of a capping $\left\{\mathrm{Mo}^{\mathrm{V}} \mathrm{O}_{2}\right\}^{2+}$ unit thus leading to the formation of a chain (Fig. 2a). Bond valence sum calculations (BVS, Fig. S5) are consistent with

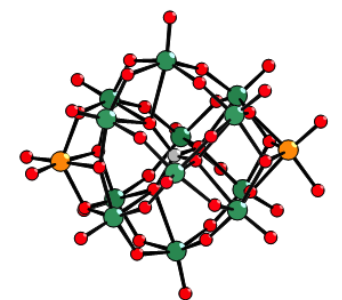

a)

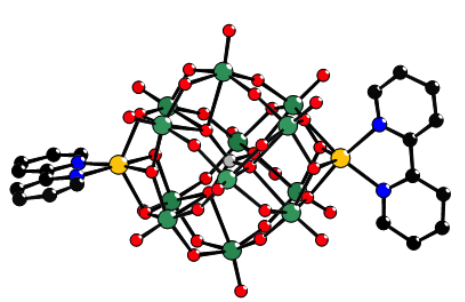

b) 
Fig. 1 Ball and stick representations of the POM units in a) Ru$\mathbf{P M o}_{14}$ and b) Ru-PMo $\mathbf{P M}_{12} \mathbf{Z n}_{\mathbf{2}}$. Gray spheres: P, green spheres: Mo, yellow spheres: $\mathrm{Zn}$, orange spheres: $\mathrm{Mo}^{\mathrm{V}}$, red spheres: $\mathrm{O}$, blue spheres: $\mathrm{N}$, black spheres: $\mathrm{C}$; hydrogen atoms have been omitted for clarity.

$\mathrm{a}+\mathrm{V}$ oxidation state for the capping Mo ions. The Mo13, $\mathrm{O} 33$ and Mo14 atoms are almost aligned (Fig. 2c). Besides the equally shared $\mathrm{O} 33$ oxygen atom and four bridging $\mathrm{O}$ atoms of the Keggin core, the capping Mo ions are bound to one terminal $\mathrm{O}$ atom with short $\mathrm{Mo}=\mathrm{O}$ bond lengths. The two terminal atoms are trans to each other. The geometry of this anti $\left\{\mathrm{Mo}_{2} \mathrm{O}_{2}\left(\mu_{2}-\mathrm{O}\right)\right\}^{4+}$ unit is close to that observed in the dinuclear complex $\left[\mathrm{Mo}_{2} \mathrm{O}_{3}\left(\mathrm{C}_{2} \mathrm{O}_{4}\right)_{4}\right]^{4-27}$ (Fig. S7). It can be noted that such connection mode between two $\mathrm{Mo}^{\mathrm{V}}$ ions is rarely encountered. Indeed the most common dimolybdenum( $\mathrm{V}$ ) bridge is the $\left\{\mathrm{Mo}_{2} \mathrm{O}_{2}\left(\mu_{2}-\mathrm{O}\right)_{2}\right\}^{2+}$ unit where the two $\mathrm{Mo}^{\mathrm{V}}$ ions are bound via two $\mu$-oxo bridges, the two $\mathrm{Mo}^{\mathrm{v}}$ ions being also involved in a $\mathrm{Mo}^{\mathrm{V}}-\mathrm{Mo}^{\mathrm{V}}$ bound (Fig. S7). To our knowledge such a connection has never been observed in polymeric Keggin chains. A single $\mathrm{Mo}^{\mathrm{V}}$ $\mathrm{O}-\mathrm{Mo}^{\mathrm{V}}$ linkage is encountered in the 1D inorganic polymer [ $\alpha$ $\left.\mathrm{PMo}^{\mathrm{VI}}{ }_{10} \mathrm{Mo}_{2}{ }_{2} \mathrm{O}_{39}\right]^{3-}$. Erreur! Signet non défini. However in this latter compound the Keggin ions are directly connected by a common terminal oxygen atom of the Keggin core and not through extra capping groups. In the other structures of chains with Keggin ions linked by capping and bridging units, the bridging metal ions share two $\mathrm{O}^{2-}$ ions like for example in the heteropolyoxoniobate $\left[\mathrm{SiNb}_{12} \mathrm{O}_{40}\left\{\mathrm{Nb}_{2} \mathrm{O}_{2}\left(\mathrm{H}_{2} \mathrm{O}\right)_{2}\right\}\right]^{10-28}$ and in the $\left[\alpha-\mathrm{Mo}^{\mathrm{VI}}{ }_{8} \mathrm{~V}^{\mathrm{IV}}{ }_{4} \mathrm{O}_{36}\left(\mathrm{~V}^{\mathrm{V}} \mathrm{O}_{4}\right)\right]^{7-}$ polymeric compound.Erreur! Signet non défini.

Parallel chains stack in Ru-PMo ${ }_{14}$ (Fig. 2c). In both structures $\left[\mathrm{Ru}(\mathrm{bpy})_{3}\right]^{2+}$ counter-ions are located in the voids left by the anions and, as already observed for ionic structures with $\left[\mathrm{Ru}(\mathrm{bpy})_{3}\right]^{2+}$ complexes and Lindqvist or octamolybdate POMs, ${ }^{29}$ extensive C$\mathrm{H} \cdots \mathrm{O}$ hydrogen bond interactions between the bpy ligand and the bridging and terminal $\mathrm{O}$ atoms of the POM can be observed (Fig. S8 and S9). Furthermore, $\pi-\pi$ interactions can be identified between the bpy ligands of the Ru complex and that of the $\{\mathrm{Zn}(\mathrm{bpy})\}^{2+}$ capping groups.

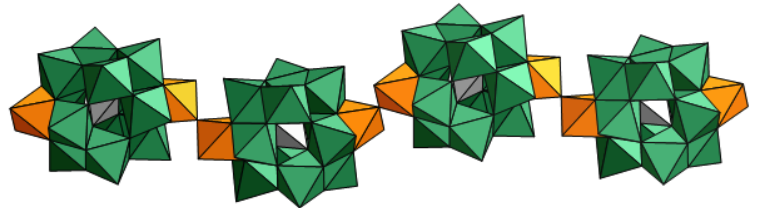

a)
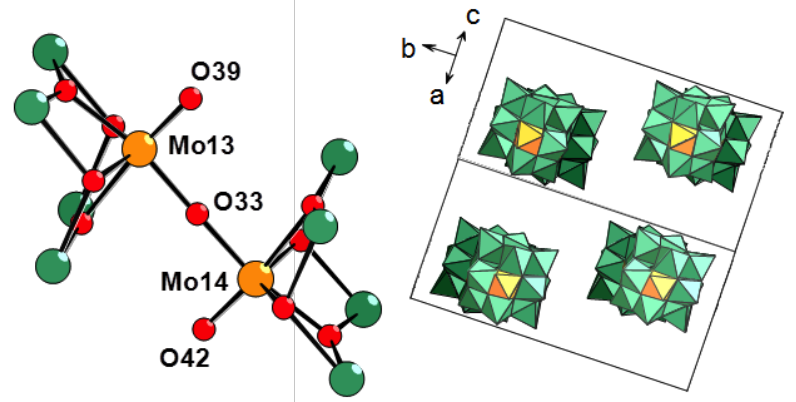

c)

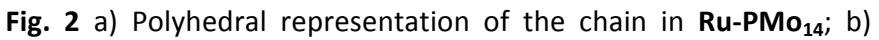
detail of the connection of the POM units in the chain, Mo13-039=

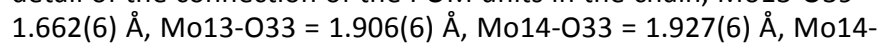
$\mathrm{O} 42=1.682(6) \AA$, Mo13-O33-Mo14 = 177.6(4) ${ }^{\circ}$, Mo13 $\cdots$ Mo14 =
3.8319(1) $\AA$; c) view of the unit cell showing the packing of the chains.

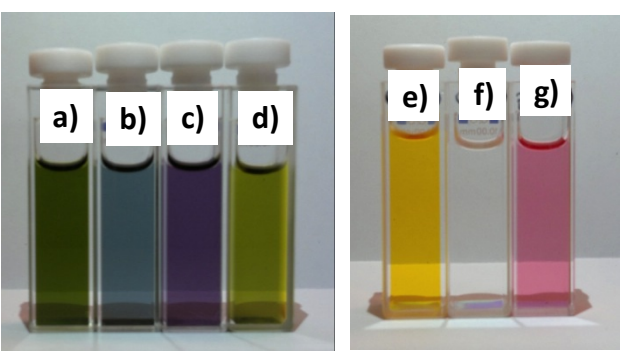

Fig. $310^{-4}$ M DMSO solutions of a) Ru-PMo ${ }_{12} Z n_{2}$, b) Co-PMo ${ }_{12} Z_{2}$, c) Fe-PMo ${ }_{12} \mathrm{Zn}_{2}$, d) Ru-PMo ${ }_{14}$, e) $\left[\mathrm{Ru}(\mathrm{bpy})_{3}\right]^{2+}$, f) $\left[\mathrm{Co}(\mathrm{bpy})_{3}\right]^{2+}$, and g) $\left[\mathrm{Fe}(\mathrm{bpy})_{3}\right]^{2+}$.

\section{Solution characterisations}

The four compounds can be dissolved in DMSO $(2 \mathrm{mg}$ in $3 \mathrm{~mL}$ of DMSO (ca. $10^{-4} \mathrm{M}$ solutions)). Solutions of Ru-PMo ${ }_{12} \mathrm{Zn}_{2}$, Co$\mathbf{P M O}_{12} \mathbf{Z n}_{2}, \mathbf{F e}-\mathbf{P M o}_{12} \mathbf{Z n}_{\mathbf{2}}$ and $\mathbf{R u}-\mathbf{P M o}_{14}$ are khaki green, blue, purple and greenish yellow respectively (Fig. 3). These colours can be seen as the superimposition of the blue colour of the reduced Keggin POMs and of the $\left[\mathrm{M}(\mathrm{bpy})_{3}\right]^{2+}$ complexes. The ${ }^{31} \mathrm{P}$ NMR spectra in DMSO- $d_{6}$ solution of Ru-PMo ${ }_{14}$ (Fig. 4a) and Fe-PMo ${ }_{12} \mathbf{Z n}_{2}$ (Fig. 4b) which respectively contain diamagnetic $\left[\mathrm{Ru}(\mathrm{bpy})_{3}\right]^{2+}$ and $\left[\mathrm{Fe}(\mathrm{bpy})_{3}\right]^{2+}$ counterions - can be compared to the spectrum of the TBA salt of $\left[\alpha-\mathrm{PMo}_{12} \mathrm{O}_{40}\right]^{3-}$ (Fig. 4c). While the spectrum of $\mathbf{F e}-\mathbf{P M O}_{12} \mathbf{Z n}_{2}$ exhibits a signal at $-3.9 \mathrm{ppm}$, close to the chemical shift of the Keggin structure $\left[\mathrm{PMo}_{12} \mathrm{O}_{40}\right]^{3-}$ observed at $-3.4 \mathrm{ppm}$ in similar conditions, the spectrum of Ru-PMo ${ }_{14}$ shows a much shielded signal at $-6.2 \mathrm{ppm}$. Such a difference on the ${ }^{31} \mathrm{P}$ chemical shifts may arise from the difference in the nature of the capping metallic centre with weak paramagnetic effects. In addition, the infinite chain structure of Ru-PMo $\mathbf{P M}_{14}$ observed in solid state must result in finite molecular objects in solution. By using pulse-field gradient echo (PFGE) NMR technique, one can estimate the size and behaviour of such soluble species in solution. ${ }^{30}{ }^{31} \mathrm{P}$ diffusion ordered NMR spectroscopy (DOSY) of Ru-PMo $\mathbf{P M}_{14}$ revealed a diffusion coefficient $D$ of the dissolved species of $70 \mu \mathrm{m}^{2} / \mathrm{s}$ (Fig. 4d), that corresponds to an effective hydrodynamic radius of $15.7 \AA$ using the StokesEinstein equation $r=k T / 6 \pi \eta D$, where $k$ is the Boltzmann constant, $\eta$ is the viscosity of DMSO (1.99 mP.s), and $T$ the absolute temperature $(298 \mathrm{~K})$. When compared to the Keggin $\left[\mathrm{PMo}_{12} \mathrm{O}_{40}\right]^{3-}$ used as a reference with $D$ of $200 \mu \mathrm{m}^{2} / \mathrm{s}$ providing a radius $r$ of $5.5 \AA$ (11 $\AA$ in diameter) (Fig. 4d), ${ }^{31}$ it appears clearly that the dissolved species of Ru-PMo $\mathbf{P}_{14}$ are greater in size than a simple bicapped Keggin structure. The length of a dimer structure would be $22.3 \AA$, while a trimer form would give $32.7 \AA$ (Fig. S10) on the basis of the crystallographic structure of Ru-PMo $\mathbf{1 4}_{14}$. The diffusive species in Ru$\mathrm{PMO}_{14}$ solution with measured hydrodynamic diameter of $31.4 \AA$ would thus rather correspond to a dimeric form of a bicapped Keggin POM, with the abbreviated formula $\mathrm{Mo}\left(\mathrm{PMo}_{12}\right) \mathrm{Mo}-\mathrm{O}-$ $\mathrm{Mo}\left(\mathrm{PMo}_{12}\right) \mathrm{Mo}$. Indeed, a trimer $\mathrm{Mo}\left(\mathrm{PMo}_{12}\right) \mathrm{Mo}-\mathrm{O}-\mathrm{Mo}\left(\mathrm{PMo}_{12}\right) \mathrm{Mo}-\mathrm{O}-$ $\mathrm{Mo}\left(\mathrm{PMo}_{12}\right) \mathrm{Mo}$ with two peripheral Keggin units and one central 
Keggin unit would lead to two nonequivalent phosphorus atoms with a 2:1 ratio. Solvation shell and the elongated shape (non spherical) of the dimeric form could explain the difference in diffusion coefficients between the experimentally observed and the expected values for such a species.

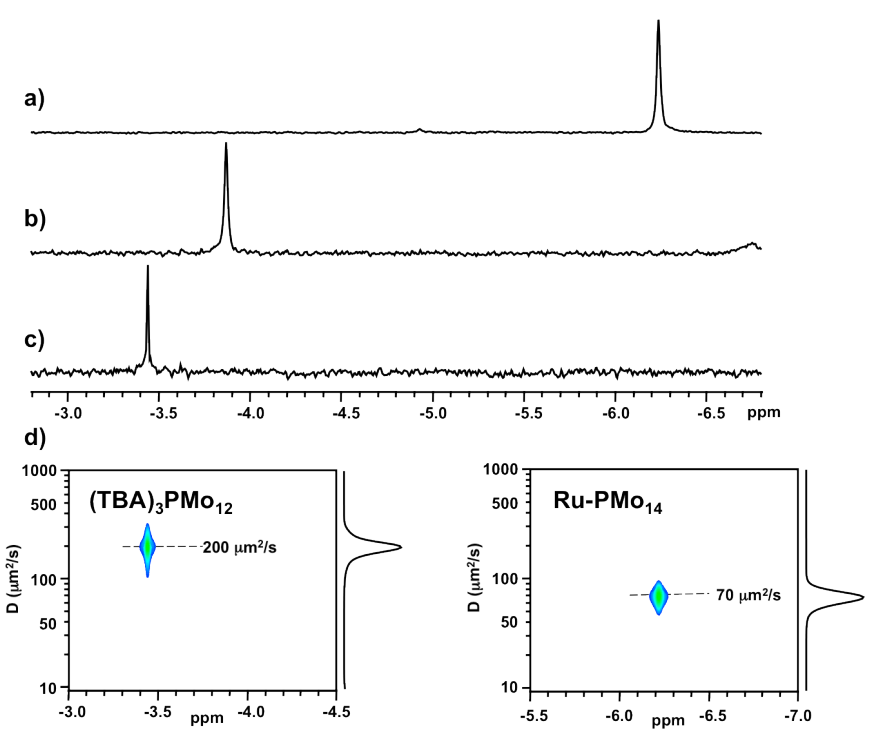

Fig. 4. ${ }^{31} \mathrm{P}$ NMR spectra of DMSO- $d_{6}$ solutions of a) Ru-PMo $\mathbf{O}_{14}$, b) Fe$\mathrm{PMo}_{12} \mathrm{Zn}_{2}$, and c) (TBA) ${ }_{3} \mathrm{Mo}_{12} \mathrm{O}_{40} ;$ d) ${ }^{31} \mathrm{P}$ DOSY NMR spectra of Ru$\mathrm{PMo}_{14}$ and $(\mathrm{TBA})_{3} \mathrm{PMo}_{12} \mathrm{O}_{40}$ in DMSO-d $d_{6}$ solution at $298 \mathrm{~K}$.

\section{Magnetic properties}

As the monomeric species are expected to be paramagnetic through the whole temperature range, only the magnetic properties of a powdered sample of $\mathbf{R u}-\mathbf{P M O}_{14}$ have been investigated. The $\chi_{M} T$ product vs. $T$ curve is represented in Fig. 5. $\chi_{M} T$ continuously decreases from $300 \mathrm{~K}\left(\chi_{M} T=0.51 \mathrm{~cm}^{3} \cdot \mathrm{mol}^{-1} . \mathrm{K}\right.$, the $\chi_{M} T$ value calculated for six unpaired electrons being $2.25 \mathrm{~cm}^{3} \cdot \mathrm{mol}^{-}$ ${ }^{1} . \mathrm{K}$ assuming $\left.g=2.0\right)$ to $2 \mathrm{~K}\left(\chi_{\mathrm{M}} T=0.02 \mathrm{~cm}^{3} \cdot \mathrm{mol}^{-1} \cdot \mathrm{K}\right)$. This is indicative of antiferromagnetic interactions between the $d^{1}$ electrons of the six $\mathrm{Mo}^{\mathrm{V}}$ centers. Based on the BVS calculations, it

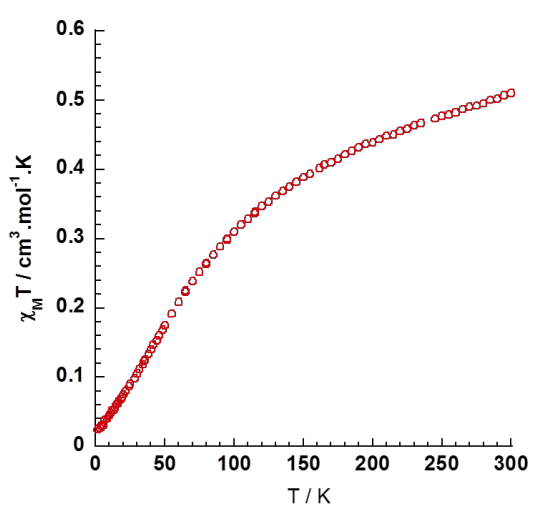

Fig. 5 Thermal behaviour of $\chi_{M} T$ for Ru-PMo ${ }_{14}$ at 1000 Oe in the $2-$ $300 \mathrm{~K}$ range. has been proposed that the capping molybdenum ions are in the $+\mathrm{V}$ oxidation state (see above). This implies that the $\mathrm{PMo}_{12}$ core contains four $d^{1}$ electrons. It is well-known that reduced Keggin or Lindqvist POMs containing an even number of electrons are diamagnetic even at room temperature due to strong antiferromagnetic couplings. ${ }^{32}$ Thus, it can be proposed that, magnetically, Ru-PMo ${ }_{14}$ behaves as $\left\{\mathrm{Mo}_{2}{ }_{2} \mathrm{O}_{2}\left(\mu_{2}-\mathrm{O}\right)\right\}^{4+}$ magnetic pairs connected via diamagnetic $\mathrm{PMo}_{12}$ units. This assumption is not in contradiction with the experimental curve, the high temperature $\chi_{\mathrm{M}} T$ value tending to the $0.75 \mathrm{~cm}^{3} \cdot \mathrm{mol}^{-1} . \mathrm{K}$ value expected for two uncoupled electrons (assuming $g=2.0$ ) while the low temperature data are in agreement with a singlet ground state. However, attempts to quantify the magnetic exchange in Ru-PMo ${ }_{14}$ by fitting the $\chi_{M} T$ vs. $T$ curve considering the $\hat{H}=-J \hat{S}_{M 013} \hat{S}_{M 014}$ Hamiltonian adapted for modelling dinuclear species with localized spins have failed. We have thus considered a second model where the $\left\{\mathrm{Mo}_{2}{ }_{2} \mathrm{O}_{2}\left(\mu_{2}-\mathrm{O}\right)\right\}^{4+}$ dimers do not behave as isolated pairs but are magnetically coupled via the $\mathrm{PMo}_{12}$ units. In other words, we have taken into consideration an alternating Heisenberg-chain model. ${ }^{33}$ However, again, no acceptable fit could be obtained. All this strongly suggests that the $d$ electrons of the capping molybdenum centres in Ru-PMo ${ }_{14}$ cannot be considered fully localized. DFT calculations were thus undertaken in order to consider a possible delocalization of these electrons on the $\mathrm{PMo}_{12}$ fragment.

\section{Electronic structure calculations}

DFT calculations were driven on the monomeric block of the chain, a model with formula $\left[\left(\mathrm{PMo}_{8}{ }_{8} \mathrm{Mo}_{4}{ }_{4} \mathrm{O}_{40}\right)\left(\mathrm{Mo}^{\mathrm{V}} \mathrm{O}_{2} \mathrm{H}\right)_{2}\right]^{3-}$ containing six $\mathrm{Mo}^{\mathrm{V}}$-like $\left(\mathrm{d}^{1}\right)$ electrons and two $\mathrm{H}$ atoms added to the oxygen linkers ( 033 in Fig. $2 \mathrm{~B}$ ) to saturate their valence (see Fig. S11A). Also, the dimer system has been computed, $\left[\left(\mathrm{PMo}_{8}{ }_{8} \mathrm{Mo}_{4}{ }_{4} \mathrm{O}_{40}\right)_{2}\left(\mathrm{Mo}^{\mathrm{V}} \mathrm{O}_{3}\right)_{2}\left(\mathrm{Mo}^{\mathrm{V}} \mathrm{O}_{2} \mathrm{H}\right)_{2}\right]^{6-}$, with $12 \mathrm{Mo}^{\mathrm{V}}$-like $\left(\mathrm{d}^{1}\right)$ electrons. Fig. S11B shows this model structure with 119 atoms, including two $\mathrm{H}$ in terminal positions and a charge of -6 .
(A)

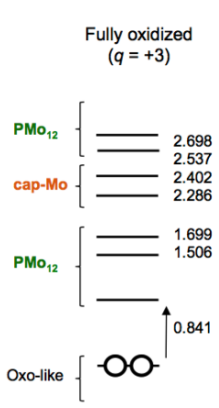

(B)

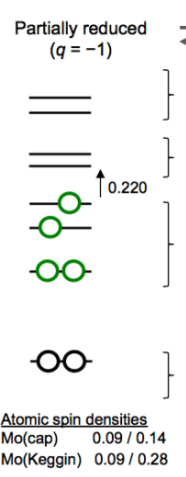

(C)

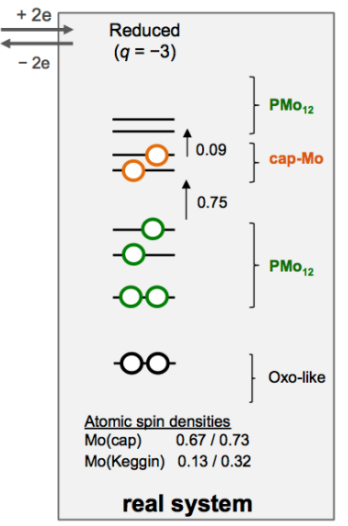

Fig. 6 Electronic structure of the monomer. Molecular orbital sequence in three different oxidation states: (A) fully oxidized $\left[\left(\mathrm{PMo}^{\mathrm{VI}}{ }_{12} \mathrm{O}_{40}\right)\left(\mathrm{Mo} \mathrm{V}^{\mathrm{V}} \mathrm{O}_{2} \mathrm{H}\right)_{2}\right]^{3+}, \quad$ (B) partially reduced $\left[\left(\mathrm{PMO}^{\mathrm{V}}{ }_{8}^{12} \mathrm{Mo}_{4}{ }_{4} \mathrm{O}_{40}\right)\left(\mathrm{Mo}^{\mathrm{V}} \mathrm{O}_{2} \mathrm{H}\right)_{2}\right]^{1-}$, and (C) real system $\left[\left(\mathrm{PMO}_{8}{ }_{8} \mathrm{Mo} \mathrm{v}_{4} \mathrm{O}_{40}\right)\left(\mathrm{MoV}_{2} \mathrm{H}\right)_{2}\right]^{3-}$. Coloured circles denote Mo electrons in different regions of the structure. Values are in $\mathrm{eV}$ and denote energy increments. Atomic spin densities proof where the Mo electrons are placed.

The resulting electronic structure for the monomeric model is 
schematically shown in Fig. $6 \mathrm{C}$ (frontier orbitals). The cases described in Fig. 6A, B and $C$ were obtained with values of $M_{S}=0,1$ and 2, respectively. The analysis of the highest occupied molecular orbitals reveals that, above the highest occupied orbital of oxo-like nature (black circles), six electrons of valence $d(\mathrm{Mo})$ character (coloured circles) are found. Among these, four are delocalized over the $\mathrm{PMo}_{12}$ Keggin unit (green) and, above them, two electrons are placed in the capping Mo atoms. This picture is coincident with the experimental data. Interestingly, less than $0.1 \mathrm{eV}$ above the levels occupied by the capping-like electrons we find empty orbitals of $\mathrm{PMo}_{12}$-like nature.

Table 1 (column $T=0 \mathrm{~K}$ ) reinforces these statements showing the computed atomic spin populations of Mo atoms. The highest net spin values correspond to the two capping Mo atoms (labelled 13 and 14 in Fig. S5). They carry one unpaired electron each. The rest of the positions feature smaller values, that is, the other metal electrons in the structure are found to be much more delocalized over Mo centres of the Keggin framework, especially those forming a four-membered ring in the equatorial region (atoms 3, 9, 10 and 11), halfway the two capping Mo atoms. In the dimeric model structure, the main features related to the spin density are preserved, confirming that one electron is localized in each cap Mo position.

We also computed other cases varying the number of $d(\mathrm{Mo})$ electrons. Taking the structure with all the metal electrons experimentally reported and gradually oxidizing it (from $C$ to $A$ in Fig. 6), we observe that the electrons in the $\mathrm{PMo}_{12}$ region persist and the ones in the capping region (orange) are removed for the latter having the highest energy. Similar schemes to those in Fig. 6

Table 1 Computed Mulliken Mo spin populations ${ }^{\mathrm{a}}$ in the monomeric unit at zero Kelvin and at higher temperatures. Values larger than 0.2 are in bold.

Atomic spin populations

$\begin{array}{lccc} & \text { OK } & 1000 \mathrm{~K} & 5000 \mathrm{~K} \\ \text { 1 Mo } & 0.133 & 0.144 & 0.172 \\ \text { 2 Mo } & 0.172 & 0.187 & \mathbf{0 . 2 2 4} \\ \text { 3 Mo } & \mathbf{0 . 3 2 3} & \mathbf{0 . 3 5 1} & \mathbf{0 . 3 3 0} \\ \text { 4 Mo } & 0.156 & 0.154 & 0.193 \\ \text { 5 Mo } & 0.129 & 0.144 & 0.173 \\ \text { 6 Mo } & 0.145 & 0.167 & \mathbf{0 . 2 1 4} \\ \text { 7 Mo } & 0.145 & 0.152 & \mathbf{0 . 2 0 5} \\ \text { 8 Mo } & 0.158 & 0.171 & \mathbf{0 . 2 1 9} \\ \text { 9 Mo } & \mathbf{0 . 2 5 2} & \mathbf{0 . 2 8 2} & \mathbf{0 . 2 9 9} \\ 10 \text { Mo } & \mathbf{0 . 3 1 9} & \mathbf{0 . 3 4 6} & \mathbf{0 . 3 2 3} \\ 11 \text { Mo } & \mathbf{0 . 2 6 0} & \mathbf{0 . 2 8 9} & \mathbf{0 . 3 1 4} \\ 12 \text { Mo } & 0.181 & 0.175 & \mathbf{0 . 2 0 6} \\ 13 \text { Mo(cap) } & \mathbf{0 . 6 7 0} & \mathbf{0 . 5 8 8} & \mathbf{0 . 3 5 4} \\ 14 \text { Mo(cap) } & \mathbf{0 . 7 2 8} & \mathbf{0 . 6 5 5} & \mathbf{0 . 3 9 8}\end{array}$

a) The $M_{s}=2$ value was used to run the calculation, that is, two paired electrons and four unpaired spin-up electrons. can be depicted for the dimer model, with localized unpaired electrons in the capping Mo atoms, and the rest of the electrons delocalized over the Keggin-like framework.

In addition to the regular electronic structure calculation ( $T=0$ $K)$, we simulated the effect of temperature upon the electron distribution on the monomer. It is introduced via the fractional orbital density (FOD), ${ }^{34}$ or $\rho^{\mathrm{FOD}}$, a real-space function of position vector $r$ :

$$
\rho^{\mathrm{FOD}}(r)=\sum_{i}^{N}\left(\delta_{1}-\delta_{2} f_{i}\right)\left|\varphi_{i}(r)\right|^{2}
$$

The sum is taken over all electronic single particle levels in the system, $\varphi_{i}$ are molecular spin orbitals and $f_{i}\left(0 \leq f_{i} \leq 1\right)$ are the fractional orbital numbers that arise from the Fermi-Dirac distribution in statistical mechanics:

$$
f_{i}=\frac{1}{e^{\left(\varepsilon_{i}-E_{F}\right) / k T_{e l}}+1}
$$

where $\left(\varepsilon_{i}-E_{F}\right)$ are orbital energy gaps. Thus, this function quantifies the accessibility of the $d(\mathrm{Mo})$ electrons to the lowest unoccupied orbitals at a given $T$. The particular values of $T_{1}=1000 \mathrm{~K}$ and $T_{2}=$ $5000 \mathrm{~K}$ taken in present calculations are not aimed at representing a realistic situation but simply a trend. These were optimized to describe the non-dynamic correlation nature of the electrons.Erreur ! Signet non défini.

The results given in Table 1 (columns $1000 \mathrm{~K}$ and $5000 \mathrm{~K}$ ) show that, as the temperature is increased (i.e. the energy available to electrons), the unpaired electrons initially localized in Mo(cap) atoms tend to migrate towards the $\mathrm{PMO}_{12}$ moiety. The decreasing spin populations of positions 13 and 14 as $T$ increases evidence this fact. Also, the higher the temperature, the larger the degree of migration. Thus, higher temperatures promote the capping-like electrons to move into the $\mathrm{PMO}_{12}$ region, thus generating a paramagnetic state represented by the High $T$ scenario in Fig. 7.

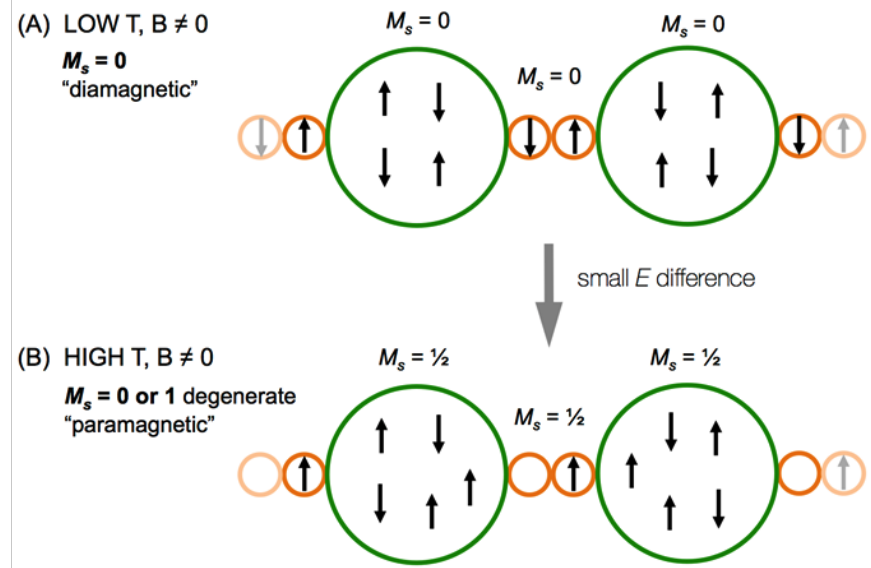

Fig. 7 Electronic distribution in a dimer of the chain. In this scheme, green circles represent the $\mathrm{PMo}_{12}$ moiety and orange circles are capping Mo atoms. Formally, four d(Mo) electrons are delocalized into each $\mathrm{PMo}_{12}$ at low $T(\mathrm{~A})$. When the system has thermal energy, one electron per monomer can be transferred from the orange 
region to the green region (B). Overall, there are two $M_{S}=1 / 2$ regions per monomer, which result in overall $M_{S}=0$ or 1 states.

This fact is in line with the small energy difference between the levels localized in capping Mo atoms (orange) and empty ones just above, of $\mathrm{PMo}_{12}$ character. The process of delocalization of these electrons is two-fold favoured: by the gain in delocalization and by the antiferromagnetic coupling with the four previously delocalized electrons in the $\mathrm{PMO}_{12}$ unit. ${ }^{35}$ They overcompensate the loss of coupling in the capping region. These computational results support the thermal dependence of the experimental magnetic susceptibility curve: low and high $T$ regions feature low and high magnetic susceptibilities, respectively. These results are also consistent with the moderate paramagnetic effect on ${ }^{31} \mathrm{P}$ nuclei as being in the centre of the Keggin shell, somehow isolated from the paramagnetic sites (capping Mo atoms).

\section{Conclusion}

Three isostructural molecular compounds with bicapped $[\alpha-$ $\left.\mathrm{PMo}_{9}{ }_{9} \mathrm{MoO}_{3} \mathrm{O}_{40}\{\mathrm{Zn}(\mathrm{bpy})\}_{2}\right]^{2-}$ anions and $\left[\mathrm{M}(\mathrm{bpy})_{3}\right]^{2+}(\mathrm{M}=\mathrm{Fe}, \mathrm{Co}, \mathrm{Ru})$ counter-cations have been isolated in the solid state. $A$ 1D polyanionic chain with $\mathrm{TBA}^{+}$and $\left[\mathrm{Ru}(\mathrm{bpy})_{3}\right]^{2+}$ counter-ions was synthesized under close synthetic conditions. This chain is built from the connection of $\left\{\alpha-\mathrm{PMo}_{8}{ }_{8} \mathrm{Mo}_{4}{ }_{4} \mathrm{O}_{40}\left\{\mathrm{MoV}_{2}\right\}_{2}\right\}$ units via a single almost linear $\mathrm{Mo}^{\mathrm{V}}-\mathrm{O}-\mathrm{Mo}^{\mathrm{V}}$ bridge between the $\mathrm{Mo}^{\mathrm{V}}$ capping ions. The four reduced and bicapped POMs represent rare examples of compounds synthesized under hydrothermal conditions that can be dissolved. The DMSO solutions exhibit a single ${ }^{31} \mathrm{P}$ NMR signal, confirming the purity of the compounds. DOSY experiments suggest that the chain compound dissociates into dimeric species. Magnetic measurements indicate that the $\mathrm{d}^{1}$ electrons of the $\mathrm{Mo}^{\mathrm{V}}$ ions of the chain (both in the Keggin core and in the bridge) are antiferromagnetically coupled at low temperature. However at high temperature a delocalization of the spin density is observed and the compound becomes paramagnetic. DFT calculations confirm the electronic distribution found experimentally at low temperature, and rationalizes the magnetic data by evidencing that at higher $T$ the capping electrons migrate into the $\mathrm{PMo}_{12}$ units, generating a paramagnetic state consistent with the $\chi T$ vs $T$ curve. This study confirms once again that the reduced $\left\{\mathrm{PMo}_{12} \mathrm{O}_{40}\right\}$ core is a versatile platform which can give access to a large variety of compounds ranging from decorated molecular complexes to $1 \mathrm{D}$ polymeric structures. These compounds are promising candidates as electroand photocatalysts ${ }^{6}$ due to the presence not only of redox active POM frameworks but also of photosensitive $\left[R u(b p y)_{3}\right]^{2+}$ counterions.

\section{Experimental section}

\section{Synthetic procedures}

$\left[\mathrm{Co}(\mathrm{bpy})_{3}\right] \mathrm{Cl}_{2}, \quad\left[\mathrm{Fe}(\mathrm{bpy})_{3}\right] \mathrm{Cl}_{2}, \quad\left[\mathrm{Ru}(\mathrm{bpy})_{3}\right] \mathrm{Cl}_{2}$ were synthesized following a reported procedure. $^{36}$ All other reagents were purchased from commercial sources and used as received. Hydrothermal syntheses were carried out in $23 \mathrm{~mL}$ polytetrafluoroethylene lined stainless steel containers under autogenous pressure. Commercially available reagents were used as received, without further purification. All reactants were briefly stirred before heating. The mixture was heated to $200^{\circ} \mathrm{C}$ over a period of $1 \mathrm{~h}$, kept at $200^{\circ} \mathrm{C}$ for $70 \mathrm{~h}$ and cooled down to room temperature over a period of $80 \mathrm{~h}$. The $\mathrm{pH}$ mixture was measured before $\left(\mathrm{pH}_{\mathrm{i}}\right)$ and after the reaction $\left(\mathrm{pH}_{\mathrm{f}}\right)$. The products were isolated by filtration after sonication which allows removing a brown powder always present after the reaction and washed with ethanol. Preparation of $\left[\mathrm{N}\left(\mathrm{C}_{4} \mathrm{H}_{9}\right)_{4}\right]\left[\mathrm{Ru}\left(\mathrm{C}_{10} \mathrm{H}_{8} \mathrm{~N}_{2}\right)_{3}\right]\left[\mathrm{PMo}_{8}{ }_{8} \mathrm{Mo}_{6}{ }_{6} \mathrm{O}_{43}\right] \quad$ (Ru$\left.\mathbf{P M O}_{14}\right)$ : A mixture of $\mathrm{Na}_{2} \mathrm{MoO}_{4} \cdot 2 \mathrm{H}_{2} \mathrm{O}(0.210 \mathrm{~g}, 0.87 \mathrm{mmol})$, molybdenum powder $99.99 \%$ (0.015 g, $0.15 \mathrm{mmol}), \mathrm{H}_{3} \mathrm{PO}_{3}(0.015 \mathrm{~g}$, $0.187 \mathrm{mmol}), \mathrm{Zn}\left(\mathrm{CH}_{3} \mathrm{COO}\right)_{2} \cdot 2 \mathrm{H}_{2} \mathrm{O}(0.052 \mathrm{~g}, 0.24 \mathrm{mmol}), 1,4-$ benzene-dicarboxylic (terephtalic acid) $(0.022 \mathrm{~g}, 0.125 \mathrm{mmol})$, $\left[\mathrm{Ru}(\mathrm{bpy})_{3}\right] \mathrm{Cl}_{2}(0.046 \mathrm{~g}, 0.061 \mathrm{mmol})$, tetrabutylammonium hydroxide 40 w.t. \% solution in water $(50 \mu \mathrm{L}, 0.075 \mathrm{mmol})$ and $\mathrm{H}_{2} \mathrm{O}$ $(10 \mathrm{~mL})$ were stirred at room temperature and the $\mathrm{pH}$ was adjusted to 4 with $4 \mathrm{M} \mathrm{HCl}\left(\mathrm{pH}_{\mathrm{f}}=3.2\right)$. The solution was degassed with $\mathrm{Ar}$ before heating. Black crystals suitable for X-ray diffraction study were collected after filtration $(0.040 \mathrm{~g}, 23 \%$ based on Ru$)$. Anal. calc. for $\mathrm{C}_{46} \mathrm{H}_{60} \mathrm{~N}_{7} \mathrm{Mo}_{14} \mathrm{O}_{43} \mathrm{PRu}$ (2874.2 g, found): $\mathrm{C} 19.22$ (18.59), $\mathrm{H}$ 2.10 (2.05), N 3.41 (3.16), Mo 46.73 (47.27), Ru 3.52 (3.18). IR $\left(\mathrm{v} / \mathrm{cm}^{-1}\right): 1600(w), 1482(w), 1461(w), 1447(\mathrm{~m}), 1419(w), 1377(w)$, 1312(w), 1270(w), 1243(w), 1168(w), 1119(w), 1070(w), 1024(w), 973(sh), 946(s), 797(m), 762(m), 728(w), 698(m), 688(m), 626(m), 497(w), 434(m).

Preparation of $\left[\mathrm{Fe}\left(\mathrm{C}_{10} \mathrm{H}_{8} \mathrm{~N}_{2}\right)_{3}\right]\left[\mathrm{PMo}^{\mathrm{VV}}{ }_{9} \mathrm{Mo}_{3}^{\mathrm{V}} \mathrm{O}_{40} \mathrm{Zn}_{2}\left(\mathrm{C}_{10} \mathrm{H}_{8} \mathrm{~N}_{2}\right)_{2}\right] \cdot 2 \mathrm{H}_{2} \mathrm{O}$ $\left(\mathrm{Fe}-\mathrm{PMo}_{12} \mathrm{Zn}_{2}\right):$ A mixture of $\left(\mathrm{NH}_{4}\right)_{6} \mathrm{Mo}_{7} \mathrm{O}_{24} \cdot 4 \mathrm{H}_{2} \mathrm{O}(0.309 \mathrm{~g}, 0.25$ mmol), molybdenum powder $99.99 \%(0.030 \mathrm{~g}, 0.31 \mathrm{mmol}), \mathrm{H}_{3} \mathrm{PO}_{3}$ $(0.030 \mathrm{~g}, 0.375 \mathrm{mmol}), \mathrm{Zn}\left(\mathrm{CH}_{3} \mathrm{COO}\right)_{2} \cdot 2 \mathrm{H}_{2} \mathrm{O}(0.105 \mathrm{~g}, 0.5 \mathrm{mmol}), 2,2^{\prime}-$ bipyridine $(0.039 \mathrm{~g}, 0.25 \mathrm{mmol}),\left[\mathrm{Fe}(\mathrm{bpy})_{3}\right] \mathrm{Cl}_{2}(0.125 \mathrm{~g}, 0.25 \mathrm{mmol})$, tetrabutylammonium hydroxide 40 w.t. \% solution in water $(50 \mu \mathrm{L}$, $0.075 \mathrm{mmol})$ and $\mathrm{H}_{2} \mathrm{O}(10 \mathrm{~mL})$ were stirred at room temperature and the $\mathrm{pH}$ was adjusted to 5 with $4 \mathrm{M} \mathrm{HCl}\left(\mathrm{pH}_{\mathrm{f}}=3.6\right)$. Black crystals suitable for $\mathrm{X}$-ray diffraction study were collected after filtration ( $0.082 \mathrm{~g}, 23 \%$ based on bpy). Anal. calc. for $\mathrm{C}_{50} \mathrm{H}_{44} \mathrm{~N}_{10} \mathrm{FeMo}_{12} \mathrm{O}_{42} \mathrm{PZn}_{2}$ (2826.3 g, found): C 21.25 (21.18), H 1.59 (1.82), N 4.95 (4.54), Fe 1.98 (1.53), Mo 40.73 (40.17), P 1.09 (1.11), Zn 4.63 (4.81). IR (v/cm $\left.{ }^{1}\right)$ : $1695(\mathrm{~m}), 1667(\mathrm{~m}), 1469(\mathrm{~m}), 1437(\mathrm{~m}), 1313(\mathrm{~m}), 1282(\mathrm{w})$, 1242(w), 1177(w), 1167(w), 1104(w), 1019(w), 932(s), 750(s), 726(s), 649(w), 580(m), 516(m), 466(m).

Preparation of $\left[\mathrm{Co}\left(\mathrm{C}_{10} \mathrm{H}_{8} \mathrm{~N}_{2}\right)_{3}\right]\left[\mathrm{PMo}_{9}{ }_{9} \mathrm{Mo}_{3} \mathrm{O}_{40} \mathrm{Zn}_{2}\left(\mathrm{C}_{10} \mathrm{H}_{8} \mathrm{~N}_{2}\right)_{2}\right] \cdot 2 \mathrm{H}_{2} \mathrm{O}$ (Co-PMo ${ }_{12} \mathrm{Zn}_{2}$ ): A mixture of $\left(\mathrm{NH}_{4}\right)_{6} \mathrm{Mo}_{7} \mathrm{O}_{24} \cdot 4 \mathrm{H}_{2} \mathrm{O}(0.618 \mathrm{~g}, 0.5$ mmol), molybdenum powder $99.99 \%$ (0.030 g, $0.31 \mathrm{mmol}$ ), $\mathrm{H}_{3} \mathrm{PO}_{3}$ (0.030 g, $0.375 \mathrm{mmol}), \mathrm{ZnCl}_{2}(0.068 \mathrm{~g}, 0.5 \mathrm{mmol}), 2,2^{\prime}$-bipyridine (0.039 g, $0.25 \mathrm{mmol}),\left[\mathrm{Co}(\mathrm{bpy})_{3}\right] \mathrm{Cl}_{2}(0.150 \mathrm{~g}, 0.25 \mathrm{mmol})$, tetrabutylammonium hydroxide 40 w.t. \% solution in water $(100 \mu \mathrm{L}$, $0.15 \mathrm{mmol})$ and $\mathrm{H}_{2} \mathrm{O}(10 \mathrm{~mL})$ were stirred at room temperature and the $\mathrm{pH}$ was adjusted to 5 with $4 \mathrm{M} \mathrm{HCl}\left(\mathrm{pH}_{\mathrm{f}}=5.5\right)$. Black crystals suitable for X-ray diffraction study were collected after filtration (0.077 g, 22\% based on bpy). Anal. calc. for $\mathrm{C}_{50} \mathrm{H}_{44} \mathrm{~N}_{10} \mathrm{CoMo}_{12} \mathrm{O}_{42} \mathrm{PZn}_{2}$ (2829.9 g, found): C 21.23 (21.77), H 1.57 (1.97), N 4.95 (4.76), Co 2.08 (2.63), Mo 40.69 (39.88), P 1.09 (1.06), Zn 4.62 (3.92). IR (v/cm $\left.{ }^{-1}\right):$ 1697(m), 1666(m), 1469(m), 1437(m), $1310(m), 1280(w), 1247(w), 1167(w), 1163(w), 1069(w), 1019(m)$, 932(s), 760(s), 732(s), 649(w), 584(m), 511(m), 467(m).

Preparation of $\left[\mathrm{Ru}\left(\mathrm{C}_{10} \mathrm{H}_{8} \mathrm{~N}_{2}\right)_{3}\right]\left[\mathrm{PMO}^{\mathrm{VI}}{ }_{9} \mathrm{Mo}_{3}{ }_{3} \mathrm{O}_{40} \mathrm{Zn}_{2}\left(\mathrm{C}_{10} \mathrm{H}_{8} \mathrm{~N}_{2}\right)_{2}\right] \cdot 4 \mathrm{H}_{2} \mathrm{O}$ (Ru-PMo $\left.\mathrm{PM}_{12} \mathrm{Zn}_{2}\right):$ A mixture of $\left(\mathrm{NH}_{4}\right)_{6} \mathrm{Mo}_{7} \mathrm{O}_{24} \cdot 4 \mathrm{H}_{2} \mathrm{O}(0.618 \mathrm{~g}, 0.5$ 
mmol), molybdenum powder $99.99 \%(0.030 \mathrm{~g}, 0.31 \mathrm{mmol}), \mathrm{H}_{3} \mathrm{PO}_{3}$ (0.030 g, $0.375 \mathrm{mmol}), \mathrm{Zn}\left(\mathrm{CH}_{3} \mathrm{COO}\right)_{2} \cdot 2 \mathrm{H}_{2} \mathrm{O}(0.109 \mathrm{~g}, 0.5 \mathrm{mmol}), 2,2^{\prime}-$ bipyridine $(0.039 \mathrm{~g}, 0.25 \mathrm{mmol}),\left[\mathrm{Ru}(\mathrm{bpy})_{3}\right] \mathrm{Cl}_{2}(0.186 \mathrm{~g}, 0.25 \mathrm{mmol})$, tetrabutylammonium hydroxide 40 w.t. \% solution in water $(100 \mu \mathrm{L}$, $0.15 \mathrm{mmol})$ and $\mathrm{H}_{2} \mathrm{O}(10 \mathrm{~mL})$ were stirred at room temperature and the $\mathrm{pH}$ was adjusted to 5 with $4 \mathrm{M} \mathrm{HCl}\left(\mathrm{pH}_{\mathrm{f}}=5.2\right)$. Black crystals suitable for $\mathrm{X}$-ray diffraction study were collected after filtration (0.107 g, 29\% based on bpy). Anal. calc. for $\mathrm{C}_{50} \mathrm{H}_{48} \mathrm{~N}_{10} \mathrm{Mo}_{12} \mathrm{O}_{44} \mathrm{PRuZn}_{2}$ (2907.5 g, found): C 20.65 (21.92), H 1.68 (2.03), N 4.82 (4.49), Mo 39.59 (39.17), P 1.06 (1.08), Ru 3.47 (2.89), Zn 4.49 (4.24) IR (v/cm $\left.{ }^{-1}\right):$ 1699(m), 1667(m), 1464(m), 1443(m), $1420(\mathrm{~m}), 1315(\mathrm{~m}), 1268(\mathrm{w}), 1242(\mathrm{w}), 1167(\mathrm{w}), 1067(\mathrm{w}), 1023(\mathrm{~m})$, 932(s), 787(s), 760(s), 724(s), 687(m), 584(m), 510(m), 472(m).

\section{Physical methods}

Infrared spectra were recorded on a Nicolet 6700 FT-IR spectrophotometer. Single crystal $X$-ray diffraction data collections were carried out by using a Siemens SMART threecircle diffractometer equipped with a CCD bidimensional detector using the monochromatised wavelength $\lambda($ Mo $K \alpha)=$ $0.71073 \AA$. Absorption correction was based on multiple and symmetry-equivalent reflections in the data set using the SADABS program ${ }^{37}$ based on the method of Blessing. ${ }^{38}$ The structure was solved by direct methods and refined by fullmatrix least-squares using the SHELX-TL package. ${ }^{39}$ Crystallographic data are given in Table 2 and the complete data can be found in the cif file as Supporting Information. Powder X-ray diffraction data was obtained on a Brüker D5000 diffractometer using Cu radiation (1.54059 ̊̊).

Table 2 Crystallographic data for Ru-PMo ${ }_{12} \mathbf{Z n}_{2}$ and $\mathbf{R u}-\mathbf{P M o}_{14}$

\begin{tabular}{|c|c|c|}
\hline & $R u-P M o_{12} Z_{2}$ & Ru-PMo 14 \\
\hline Empirical formula & \multicolumn{2}{|c|}{$\begin{array}{l}\mathrm{C}_{100} \mathrm{H}_{97} \mathrm{Mo}_{24} \mathrm{~N}_{20} \mathrm{O}_{88} \mathrm{P}_{2} \mathrm{RC}_{46} \mathrm{H}_{60} \mathrm{Mo}_{14} \mathrm{~N}_{7} \mathrm{O}_{43} \mathrm{PRu} \\
\mathrm{u}_{2} \mathrm{Zn}_{4}\end{array}$} \\
\hline Formula weight, $g$ & 5815.10 & 2874.21 \\
\hline Crystal system & orthorhombic & monoclinic \\
\hline Space group & Pcab & $P 2_{1} / n$ \\
\hline$a / \AA$ & $23.752(1)$ & $16.279(1)$ \\
\hline$b / \AA$ & $26.287(2)$ & $26.892(1)$ \\
\hline$c / \AA$ & $27.569(1)$ & $18.665(1)$ \\
\hline$\alpha /^{\circ}$ & 90 & 90 \\
\hline$\beta /{ }^{\circ}$ & 90 & $103.107(1)$ \\
\hline$\gamma /{ }^{\circ}$ & 90 & 90 \\
\hline$V / \AA^{3}$ & $17213(2)$ & $7958.0(7)$ \\
\hline$Z$ & 4 & 4 \\
\hline$\rho_{\text {calc }} / \mathrm{g} \mathrm{cm}^{-3}$ & 2.244 & 2.399 \\
\hline$\mu / \mathrm{mm}^{-1}$ & 2.510 & 2.420 \\
\hline Temperature & Room Temperature & Room Temperature \\
\hline Data / Parameters & $19761 / 1079$ & 23044 / 1013 \\
\hline$R_{\text {int }}$ & 0.0986 & 0.0828 \\
\hline GOF & 0.902 & 0.992 \\
\hline$R(>2 \sigma(I))$ & $\begin{array}{l}R_{1}^{a}=0.0643 \\
w R_{2}{ }^{\mathrm{b}}=0.1672\end{array}$ & $\begin{array}{l}R_{1}^{a}=0.0634 \\
w R_{2}{ }^{b}=0.1275\end{array}$ \\
\hline$a_{R_{1}}=\frac{\sum\left|F_{o}\right|-\left|F_{c}\right|}{\sum\left|F_{c}\right|}$ & $b_{w R_{2}}=$ & $\frac{\sum w\left(F_{o}^{2}-F_{c}^{2}\right)^{2}}{\sum w\left(F_{o}^{2}\right)^{2}}$ \\
\hline
\end{tabular}

\section{NMR measurements}

All NMR measurements were recorded at $25^{\circ} \mathrm{C}$ using a $5 \mathrm{~mm}$ sample tube in DMSO- $d_{6}$ solution with a typical concentration range of ca. $10 \mathrm{mmol} . \mathrm{L}^{-1}$. The ${ }^{31} \mathrm{P}$ NMR spectra were obtained by using a Bruker AVANCE $400 \mathrm{MHz}$ spectrometer, referenced to $85 \% \mathrm{H}_{3} \mathrm{PO}_{4}$ as an external standard. Free induction decays (FIDs) were accumulated with pulse lengths of $15 \mu$ s $\left(90^{\circ}\right.$ pulse), a recycle time of $10 \mathrm{~s}$, and a total number of FIDs of ca. 7000. DOSY NMR measurements were carried out using bipolar pulse pair stimulated echo longitudinal eddy current delay (BPP-STE-LED). The diffusion and gradient times were fixed to $\Delta=300 \mathrm{~ms}$ and $\delta=4 \mathrm{~ms}$, respectively, while the gradient strength was varied in the range $0.007-0.32 \mathrm{~T} / \mathrm{m}$. Diffusion coefficients $D$ were calculated by an inverse Laplace transform (ILT) of the signal decay data based on the Maximum Entropy method using the NMRnoteBook 2.60 program.

\section{Magnetic measurements}

Magnetic susceptibility measurements were carried out on a polycrystalline sample of $\mathbf{R u}-\mathbf{P M O}_{\mathbf{1 4}}$ using a Quantum Design MPMS-XL7 SQUID magnetometer operating in the 300-2 K temperature range. Susceptibility measurements were performed within an applied field of 1000 Oe. Pascal's constants were utilized to estimate diamagnetic corrections, the value in each case being subtracted from the experimental susceptibility data to give the molar magnetic susceptibility $\left(\chi_{M}\right)$.

\section{Electronic structure calculations}

The density functional theory (DFT) as implemented in the ADF 2016 package $^{40}$ was applied as computational approach to go deeper into the electronic structure of the chain system. Single point calculations with the $\mathrm{X}$-ray geometry were driven on the dimeric and the monomeric units. The unrestricted formalism for open-shell configurations was used taking a Slater-type basis set of triple- $\zeta$ + polarization quality, with a large frozen core of electron shells to save computational time. The zeroth-order regular approximation (ZORA) ${ }^{41}$ was introduced to account for relativistic effects. We adopted the GGA-type OPBE ${ }^{42}$ functional, and the conductor-like screening model $(\mathrm{COSMO})^{43}$ with the shielding constant of water to simulate the external stabilizing effect of the crystal.

\section{Conflicts of interest}

There are no conflicts to declare.

\section{Acknowledgements}


This work was supported by the Ministère de I'Enseignement Supérieur et de la Recherche, the CNRS, the Université de Versailles Saint Quentin en Yvelines, the Université Paris-Sud, the Université de Toulouse and a public grant overseen by the French National Research Agency (ANR) as part of the "Investissements d'Avenir" program (Labex CHARMMMAT: ANR-11-LABX-0039-grant). Guillaume Rousseau, Clotilde Menet and Khaoula Mazouzi are gratefully acknowledged for their participation in the synthesis and characterizations of the materials. Xavier López thanks financial support from the Spanish Government (project CTQ2017-83566-P).

\section{Notes and references}

1 (a) H. N. Miras, J. Yan, D.-L. Long and L. Cronin, Chem. Soc. Rev., 2012, 41, 7403; (b) A. Proust, B. Matt, R. Villanneau, G. Guillemot, P. Gouzerh and G. Izzet, Chem. Soc. Rev., 2012, 41, 7605; (c) A. Sartorel, M. Bonchio, S. Campagna and F. Scandola, Chem. Soc. Rev., 2013, 42, 2262; (d) B. S. Bassil and U. Kortz, Z. Anorg. Allg. Chem., 2010, 636, 2222; (e) O. Oms, A. Dolbecq and P. Mialane, Chem. Soc. Rev., 2012, 41, 7497; (f) A. Müller and P. Gouzerh, Chem. Soc. Rev., 2012, 41, 7431.

2 M. T. Pope and A. Müller, Angew. Chem. Int. Ed. Engl., 1991, 30, 34.

3 (a) D.-Y. Du, J.-S. Qin, S.-L. Li, Z.-M. Su and Y.-Q. Lan, Chem. Soc. Rev., 2014, 43, 4615; (b) N. I. Gumerova and A. Rompel, Nat. Rev. Chem., 2018, 2, doi:10.1038/s41570-018-0112; (c) G. Izzet, F. Volatron and A. Proust, Chem. Rec., 2017, 17, 250; (d) L. Vilà-Nadal and L. Cronin, Nat. Rev. Mat., 2017, 2, 17054; (e) M.-P. Santoni, G. S. Hanan and B. Hasenknopf, Coord. Chem. Rev., 2014, 281, 64.

4 (a) A. Sartorel, M. Bonchio, S. Campagna, and F. Scandola, Chem. Soc. Rev., 2013, 42, 2262; (b) J. M. Clemente-Juan, E. Coronado and A. Gaita-Ariño, Chem. Soc. Rev., 2012, 41, 7464; (c) S.-S. Wang and G.-Y. Yang, Chem. Rev., 2015, 115, 4893; (d) G. Marcì, E. I. García-López and L. Palmisano, Eur. J. Inorg. Chem., 2014, 21 ; (e) A. Bijelic, M. Aureliano and A. Rompel, Chem. Commun., 2018, 54, 1153.

5 (a) X. Lu, X. Shi, Y. Bi, C. Yu, Y. Chen and Z. Chi, Eur. J. Inorg. Chem., 2009, 5267; (b) X. Wang, X. Lu, P. Li, X. Pei, C. Ye, J. Coord. Chem., 2008, 61, 3753.

6 C. Zhang, X. Lin, Z. Zhang, L.-S. Long, C. Wang, and W. Lin, Chem. Commun., 2014, 50, 11591.

7 M. Yuan, Y. G. Li, E. B. Wang, C. G. Tian, L. Wang, N. Hu, N. H. Hu and H. Q. Jia, Inorg. Chem., 2003, 42, 3670.

8 W.-H. Chen and J.-X. Mi, Polyhedron, 2015, 85, 117.

9 Q. Chen and C. L. Hill, Inorg. Chem., 1996, 35, 2403.

10 R. Bakri, A. Booth, G. Harle, P. S. Middleton, C. Wills, W. Clegg, R. W. Harrington and R. J. Errington, Chem. Commun., 2012, 48, 2779.

11 P. Mialane, A. Dolbecq and F. Sécheresse, Chem. Commun., $2006,3477$.

12 A. Dolbecq, P. Mialane, F. Sécheresse, B. Keita and L. Nadjo, Chem. Commun., 2012, 48, 8299.

13 H. El Moll, B. Nohra, P. Mialane, J. Marrot, N. Dupré, B. Riflade, M. Malacria, S. Thorimbert, B. Hasenknopf, E. Lacôte, P. A. Aparicio, X. López, J. M. Poblet and A. Dolbecq, Chem. Eur. J., 2011, 17, 14129.

14 (a) A. Dolbecq, E. Cadot, D. Eisner and F. Sécheresse, Inorg. Chem., 1999, 38, 4217; (b) A. K. Iyer and S. C. Peter, Inorg. Chem., 2014, 53, 653.

15 Z.-G. Han, X.-Q. Chang, J.-S. Yan, K.-N. Gong, C. Zhao and X.-L. Zhai, Inorg. Chem., 2014, 53, 670.

16 Mentioned in M. I. Khan, Q. Chen, J. Salta, C. O'Connor and J. Zubieta, Inorg. Chem., 1996, 35, 1880 but never published.
17 A. Müller, M. Koop, P. Schiffels and H. Bögge, Chem. Commun., 1997, 1715.

18 Y.-H. Ren, Y.-C. Hu, Z.-P. Kong, M. Gu, B. Yue and H.-Y. He, Eur. J. Inorg. Chem., 2013, 1821.

19 (a) J. R. Galán-Mascarós, C. Giménez-Saiz, S. Triki, C. J. Gómez-García, E. Coronado and L. Ouahab, Angew. Chem. Int. Ed., 1995, 34, 1460; (b) P.-E. Car, B. Spingler, S. Weyeneth, J. Patscheider and G. R. Patzke, Polyhedron, 2013, 52, 151.

20 Y.-H Ren, Y.-C. Hu, Z.-P. Kong, M. Gu, B. Yue and H.-Y. He, Eur. J. Inorg. Chem., 2013, 1821.

21 (a) H. T. Evans, T. J. R. Weakley and G. B. Jameson, J. Chem. Soc. Dalton Trans., 1996, 2537; (b) J.-P. Wang, Y. Shen and J. Niu, J. Coord. Chem., 2007, 60, 1183.

22 L. I. Udalova, S. A. Adonin, P. A. Abramov, I. V. Korolkov, A. S. Yunoshev, P. E. Plyusnin and M. Sokolov, New J. Chem., 2016, 40, 9981.

23 K. Y. Monakhov, W. Bensch and P. Kögerler, Chem. Soc. Rev., 2015, 44, 8443.

24 (a) B. Nohra, H. El Moll, L. M. Rodriguez Albelo, P. Mialane, J. Marrot, C. Mellot-Draznieks, M. O'Keeffe, R. Ngo Biboum, J. Lemaire, B. Keita, L. Nadjo and A. Dolbecq, J. Am. Chem. Soc., 2011, 133, 13363; (b) G. Rousseau, L. M. Rodriguez-Albelo, W. Salomon, P. Mialane, J. Marrot, F. Doungmene, I.-M. Mbomekallé, P. de Oliveira and A. Dolbecq, Cryst. Growth Des., 2015, 15, 449; (c) W. Salomon, G. Paille, M. GomezMingot, P. Mialane, J. Marrot, C. Roch-Marchal, G. Nocton, C. Mellot-Draznieks, M. Fontecave and A. Dolbecq, Cryst. Growth. Des., 2017, 17, 1600.

25 P. J. Hagrman, R. L. LaDuca, H.-J. Koo, R. Rarig, R. C. Haushalter, M.-H. Whangbo and J. Zubieta, Inorg. Chem., 2000, 39, 4311.

26 (a) J. A. Fernández, X. López and J. M. Poblet, J. Mol. Catal. A: Chemical, 2007, 262, 236; (b) I. Efremenko and R. Neumann, J. Phys. Chem. A, 2011, 15, 4811.

27 B. Modec, J. V. Brenčič and J. Koller, Eur. J. Inorg. Chem., 2004, 1611.

28 Y. Hou, L. N. Zakharov and M. Nyman, J. Am. Chem. Soc., 2013, 135, 16651.

29 B. Yan, Y. Li, S. R. Calhoun, N. G. Cottrell, D. J. Lella and A. J. Celestian, Inorg. Chem. Commun., 2014, 43, 23.

30 (a) M. Haouas, D. P. Petry, M. W. Anderson and F. Taulelle, Inorganics, 2016, 4, doi:10.3390/inorganics4020018; (b) X. Li and D. F. Shantz, J. Colloid Interf. Sci., 2012, 383, 19; (c) C. Bonhomme, C. Gervais and D. Laurencin, Progr. Nuc. Magn. Reson. Spect., 2014, 77, 1.

31 K. Uehara, T. Oishi, T. Hirose and N. Mizuno, Inorg. Chem., 2013, 52, 11200.

32 a) N. Suaud, A. Gaita-Ariño, J.-M. Clemente-Juan, J. SánchezMarín and E. Coronado, J. Am. Chem. Soc., 2002, 124, 15134 and references therein; b) N. Suaud, X. Lopez, B. Amor, N. A. G. Bandeira, C. de Graaf and J. M. Poblet, J. Chem. Theor. Comput., 2015, 11, 550.

33 J. W. Hall, W. E. Marsh, R. R. Weller and W. E. Hatfield, Inorg. Chem., 1981, 20, 1033.

34 See, for details: S. Grimme and A. Hansen, Angew. Chem. Int. Ed., 2015, 54, 12308.

35 P. Parent, P. A. Aparicio, P. de Oliveira, A.-L. Teillout, J. M. Poblet, X. López and I. M. Mbomekallé, Inorg. Chem., 2014, 53, 5941.

36 J. A. Broomhead, C. G. Young and P. Hood, Inorg. Synth., 1990, 28, 338.

37 G. M. Sheldrick, SADABS, program for scaling and correction of area detector data, University of Göttingen, Germany, 1997.

38 R. Blessing, Acta Crystallogr., 1995, A51, 33. 
39 G. M. Sheldrick, SHELX-TL version 5.03, Software Package for the Crystal Structure Determination, Siemens Analytical Xray Instrument Division : Madison, WI USA, 1994.

40 (a) C. Fonseca Guerra, J. G. Snijders, G. Te Velde and E. J. Baerends, Theor. Chem. Acc. 1998, 99, 391; (b) G. Te Velde, F. M. Bickelhaupt, S. J. A. van Gisbergen, C. Fonseca Guerra, E. J. Baerends, J. G. Snijders and T. Ziegler, J. Comput. Chem., 2001, 22, 931.

41 W. Klopper, J. H. Van Lenthe and A. C. Hennum, J. Chem. Phys., 2000, 113, 9957.

42 (a) J. P. Perdew, K. Burke and M. Ernzerhof, Phys. Rev. Lett., 1996, 77, 3865; Erratum 1996, 78, 1396; (b) N. C. Handy and A. J. Cohen, Molec. Phys., 2001, 99, 403.

43 (a) A. Klamt, J. Phys. Chem., 1995, 99, 2224; (b) J. Andzelm, C. Kölmel and A. Klamt, J. Chem. Phys., 1995, 103, 9312; (c) A. Klamt and G. Schürmann, J. Chem. Soc. Perkin Trans., 1993, 2, 799; (d) C. C. Pye and T. Ziegler, Theor. Chem. Acc., 1999, $101,396$. 